\title{
Analisis Kesalahan Matematika Dikaitkan Met- Before Siswa pada Operasi Penjumlahan Pecahan Bentuk Aljabar
}

\author{
Herna \\ Universitas Sulawei Barat \\ e-mail: hernausb@rocketmail.com
}

\begin{abstract}
Abstrak
Penelitian kualitatif ini dilakukan terhadap siswa SMP kelas VIII dan bertujuan untuk menganalisi kesalahan matematika dikaitkan dengan met-before dalam menyelesaikan soal operasi penjumlahan pecahan bentuk aljabar. Data dikumpulkan melalui tes dan wawancara. Hasil penelitian menunjukkan bahwa siswa berkemampuan rendah dan sedang melakukan kesalahan prosedural dan konseptual dalam mengkonstruksi konsep penjumlahan pecahan bentuk aljabar. Pada siswa berkemampuan rendah, penyebabnya adalah tidak ada kesesuaian antara met-before siswa dengan masalah, dan pemahaman siswa terhadap pengetahuan terkait met-beforenya masih banyak yang salah. sedangkan siswa berkemampuan penyebabnya adalah met-before siswa belum cukup untuk mengkonstruksi konsep tersebut, dan pemahaman terhadap pengetahuan terkait metbefore siswa masih ada yang salah. Siswa berkemampuan tinggi memiliki met-before yang lengkap, pemahaman yang benar, dan sesuai untuk mengkonstruksi konsep penjumlahan pecahan bentuk aljabar, tetapi belum mampu mengaitkan konsep pecahan senilai dengan masalah.
\end{abstract}

Kata kunci: kesalahan matematika, met-before, operasi pecahan bentuk aljabar

\section{PENDAHULUAN}

Dalam proses belajar terjadi konstruksi konsep matematika pada siswa. Siswa dalam mengkonstruksi konsep bisa berhasil, bisa juga gagal. Proses konstruksi yang gagal menunjukkan adanya kesulitan siswa dalam memahami konsep. Kesulitan tersebut ditunjukkan oleh kesalahan matematika yang dilakukan siswa ketika mengkonstruksi suatu konsep.

Kesalahan matematika pada berbagai konsep matematika mencakup bilangan, logaritma, aljabar, dan geometri. Pada bilangan diantaranya adalah kesalahan pada operasi pengurangan bilangan, pecahan dan desimal. Riccomini (2005) mengkaji kesalahan sistematis dalam pengurangan yaitu "smaller-from-larger" (SFL) dan "borrow-across-zero" (BAZ). Yusof dan Malone (2002) mengkaji kesalahan matematika siswa dalam menyelesaikan soal perhitungan dan soal cerita pada materi pecahan. Idris dan Narayanan (2011) mengidentifikasi jenis kesalahan yang dilakukan siswa dalam operasi penjumlahan dan pengurangan pada pecahan. Dhlamini (2014) mengkaji penjumlahan pecahan pada siswa kelas IX di Afrika selatan provinsi Gauteng. Ia menemukan bahwa siswa melakukan miskonsepsi dengan menganggap penjumlahan pecahan sebagai penjumlahan bilangan asli. Lebih lanjut Yusof dan Malone (2002) menemukan jenis kesalahan matematika pada pecahan meliputi, grouping error, basic fact error, defective algorithm, incorrect operation dan careless error.

Selanjutnya, penelitian terkait kesalahan matematika pada topik logaritma, geometri, dan konsep aljabar. Ganesan dan Dindyal (2014) mengkaji kesalahan 
matematika pada topik logaritma di SMA Singapura. Huang dan Cheng (2010) mengkaji kesalahan matematika pada geometri kelas VIII. Selain itu, pada konsep aljabar diantaranya adalah topik persamaan kuadrat, menyederhanakan algebraic expressions, dan proses aljabar. Maat, dkk. (2010) mengkaji kesalahan siswa dalam belajar persamaan kuadrat. Seng (2010) mengkaji kesalahan yang dilakukan siswa laki-laki kelas VII dalam menyederhanakan algebraic expressions. Barrera, dkk. (2004) mengkaji kesalahan yang dilakukan siswa saat melakukan proses aljabar seperti substitusi formal, generalisasi dan pemodelan dalam rangka membangun prosedur untuk membantu siswa memperbaiki kesalahan mereka.

Kesalahan matematika berdasarkan proses penyelesaian masalah perhitungan diklasifikasikan dalam tiga kategori yakni, kesalahan konseptual, prosedural, dan teknis. Hal ini sejalan dengan pendapat Kiat (2005). Kesalahan konseptual merupakan kesalahan yang terjadi karena kegagalan untuk memahami konsep-konsep yang terlibat dalam masalah, atau kesalahan yang timbul dari kegagalan untuk mengapresiasi hubungan yang terlibat dalam masalah. Kesalahan prosedural adalah kesalahan yang timbul dari kegagalan untuk melaksanakan manipulasi atau algoritma meskipun memiliki pemahaman konsep terhadap masalah. Kesalahan teknis merupakan kesalahan yang terjadi karena kurangnya pengetahuan konten matematika dalam topik lain atau kesalahan karena kecerobohan. Kesalahan matematika yang akan dikaji dalam penelitian ini adalah kesalahan konseptual dan prosedural. Sedangkan kesalahan teknis tidak dikaji, karena kesalahan ini hanya terjadi akibat kecerebohan yang dilakukan siswa ketika menyelesaikan masalah matematika, sehingga dapat segera diperbaiki.

Kesalahan matematika pada suatu konsep matematika akan menyebabkan terjadinya kesalahan matematika pada konsep matematika yang lain. Hal ini sejalan dengan pendapat Maat, dkk. (2010) bahwa kesalahan siswa dalam memecahkan persamaan kuadrat disebabkan mereka lemah dalam menguasai topik-topik seperti aljabar, pecahan, bilangan negatif, dan ekspansi aljabar. Contohnya, ketika siswa melakukan kesalahan matematika pada operasi bentuk aljabar, dengan menjumlahkan atau mengurangkan suku aljabar yang tidak sejenis maka siswa pun akan melakukan kesalahan matematika ketika menyelesaikan persamaan kuadrat, karena persamaan kuadrat memuat bentuk aljabar yang terdiri atas operasi suku-suku aljabar. Untuk itu, kesalahan matematika siswa dalam menyelesaikan soal matematika perlu diperbaiki. Hal tersebut dapat ditempuh dengan lamgkah awal yakni, melakukan analisis kesalahan matematika.

Proses konstruksi konsep matematika tidak terlepas dari pengetahuan awal dan pengalaman siswa sebelumnya. Tall (2004) menyebut pengalaman sebelumnya sebagai met-before. Dalam mengkonstruksi konsep yang baru, met-before dapat memberikan efek yang positif maupun negatif (Tall, 2002). Efek negatifnya adalah met-before dapat menyebabkan konflik yang serius. Hal tersebut dimaksudkan bahwa met-before dapat memicu terjadinya kesalahan matematika dalam mengkonstruksi konsep matematika. Untuk itu, dalam penelitian ini akan dicoba dikaji kesalahan matematika dikaitkan dengan met-before siswa.

Analisis kesalahan matematika bertujuan untuk mengetahui kesalahan apa saja yang banyak dilakukan dan bagaimana met-before siswa berperan dalam terjadinya kesalahan matematika. Melalui analisis kesalahan akan ditemukan jenis dan penyebab kesalahan matematika siswa, sehingga guru dapat memikirkan jenis bantuan yang akan diberikan kepada siswa untuk memperbaiki kesalahan tersebut. Kesalahan yang dilakukan siswa dikaitkan dengan met-beforenya perlu kita analisis lebih lanjut, agar mendapatkan gambaran yang jelas dan rinci atas kelemahan kelemahan siswa dalam menyelesaikan soal materi operasi penjumlahan pecahan bentuk aljabar. Kesalahan yang dilakukan oleh 
siswa dapat digunakan sebagai bahan pertimbangan pengajaran dalam usaha meningkatkan kegiatan belajar dan mengajar. Adanya peningkatan kegiatan belajar dan mengajar diharapkan dapat memperbaiki hasil belajar atau prestasi belajar siswa.

Konsep matematika yang akan dipilih dalam penelitian ini adalah konsep aljabar. Hudojo (2003) berpendapat bahwa belajar matematika merupakan proses membangun atau mengkonstruksi konsep dan prinsip-prinsip matematika. Belajar matematika melibatkan struktur hierarki dari konsep-konsep tingkat lebih tinggi yang dibentuk berdasarkan apa yang telah terbentuk sebelumnya. Pada saat mempelajari materi matematika yang baru, penguasaan belajar yang sebelumnya akan mempengaruhi terjadinya proses belajar matematika. Salah satu kompetensi yang harus dikuasai saat belajar matematika di SMP adalah mampu menyelesaikan operasi pecahan bentuk aljabar. Penguasaan kompetensi itu sangat penting karena akan menjadi prasyarat utama pada saat siswa belajar aljabar pada tahap-tahap berikutnya.

Berdasarkan penyataan-pernyataan di atas, peneliti tertarik untuk mengkaji lebih mendalam kesalahan matematika siswa dikaitkan dengan met-beforenya pada operasi pecahan bentuk aljabar dengan melakukan penelitian terkait "Analisis Kesalahan Matematika Siswa dalam Menyelesaikan Soal Operasi Penjumlahan Pecahan Bentuk Aljabar". Tujuannya adalah untuk mengetahui jenis dan penyebab kesalahan matematika dalam menyelesaikan soal operasi penjumlahan pecahan bentuk aljabar.

\section{METODE PENELITIAN}

Jenis penelitian yang digunakan adalah penelitian deskriptif, karena dalam penelitian ini dideskripsikan jenis kesalahan matematika dan bagaimana terjadinya kesalahan matematika ditinjau dari met-before siswa. Sedangkan pendekatan yang digunakan dalam penelitian ini adalah pendekatan kualitatif karena data yang dikumpulkan dan dipaparkan dalam bentuk kata-kata yang dirangkai dalam sebuah kalimat, tidak berupa angka atau nilai.

Penelitian ini dilakukan di SMP Negeri 4 Galung Lombok, kec. Tinambung, kab. Polman, Prov. Sulawesi Barat. Data dikumpulkan melalui tes tertulis dan wawancara. Tes tertulis dimaksudkan untuk mengkaji keterkaitan antara met-before siswa dan kesalahan yang dilakukan oleh siswa dalam menyelesaikan soal operasi penjumlahan pecahan bentuk aljabar. Sedangkan, Wawancara dimaksudkan untuk menggali lebih dalam pikiran siswa untuk mendapatkan data atau informasi yang relevan tentang kesalahan matematika yang dilakukan oleh siswa dikaitkan dengan met-beforenya. Wawancara yang dilakukan adalah wawancara tidak terstruktur.

Analisis data dimulai sejak persiapan penelitian sampai dengan setelah proses pengumpulan data selesai. Setelah pengumpulan data, peneliti melakukan teknik menganalisa data melalui 3 tahap, yaitu: 1) reduksi data; 2) penyajian data; dan 3) penarikan kesimpulan.

\section{HASIL PENELITIAN DAN PEMBAHASAN}

Berikut temuan kesalahan matematika siswa dalam mengkonstruksi konsep penjumlahan pecahan bentuk aljabar. 
a. Hasil analisis kesalahan Subjek R dikaitkan dengan met-beforenya

Struktur Berpikir Subjek R

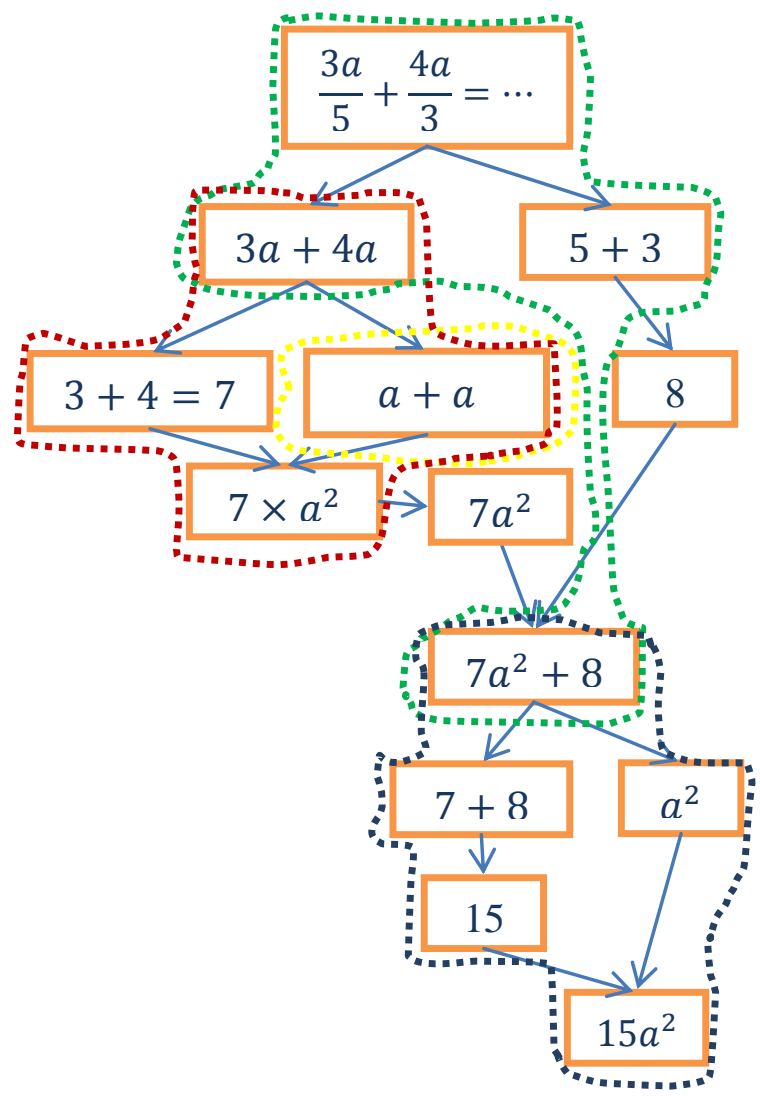

Struktur Masalah

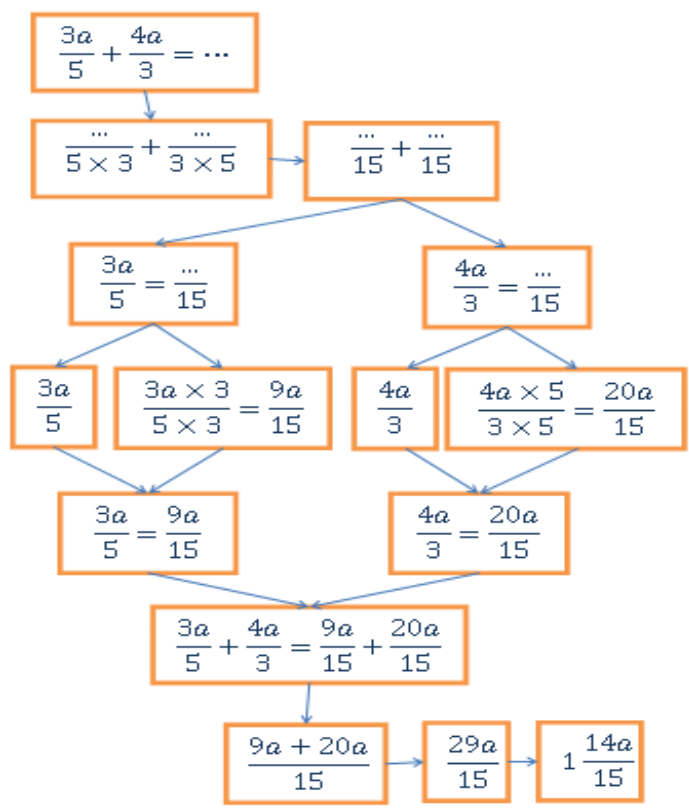

Keterangan:

" * = kesalahan procedural (KP)

..... = kesalahan konsep penjumlahan suku-suku aljabar sejenis dengan koefisien $\neq$ $1\left(\mathrm{KK}_{1}\right)$

$=$ kesalahan konsep penjumlahan suku-suku aljabar sejenis dengan koefisien 1

$\left(\mathrm{KK}_{2}\right)$

...... = kesalahan konsep penjumlahan suku-suku aljabar tidak sejenis $\left(\mathrm{KK}_{3}\right)$

Berdasarkan hasil wawancara dan hasil tes tertulis, ditemukan bahwa subjek R telah memahami soal dengan baik. Hal tersebut ditunjukkan dari struktur berpikir R yang mencoba untuk menyelesaikan operasi penjumlahan bentuk aljabar meskipun prosedur dan konsep yang digunakan masih salah. Penggunaan prosedur penyelesaian dan konsep yang masih salah ditunjukkan oleh tidak ada kesesuaian antara stuktur berpikir subjek $\mathrm{R}$ dengan struktur masalah. Berikut adalah paparan penyebab ketidaksesuian antara struktur berpikir $\mathrm{R}$ dengan struktur masalah. 
Kesalahan Prosedural

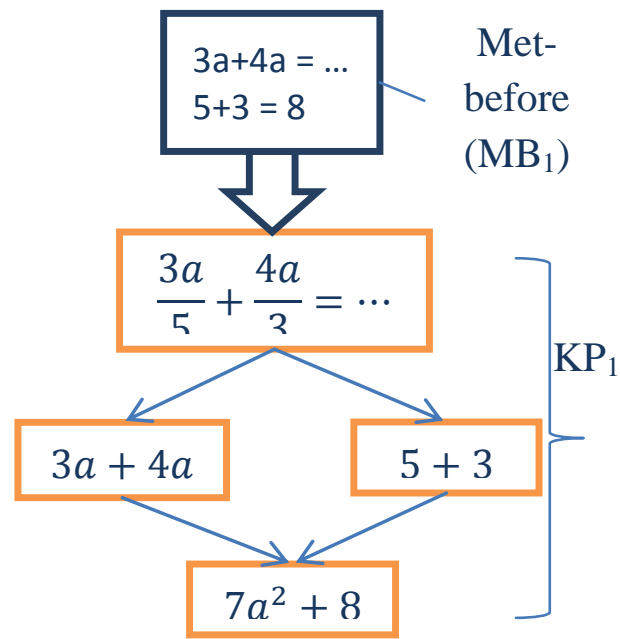

Gambar di samping menunjukkan kesalahan prosedural siswa dalam menyelesaikan operasi penjumlahan pecahan bentuk aljabar yakni, dengan menjumlahkan pembilang dengan pembilang dan penyebut dengan penyebut, kemudian menjumlahkan hasil dari masing-masing penjumlahan tersebut. Hal tersebut disebabkan oleh met-before siswa terkait operasi penjumlahan suku-suku aljabar dan operasi penjumlahan bilangan bulat, sehingga ketika mengaitkan metbefore tersebut dengan operasi penjumlahan pecahan bentuk aljabar, siswa cenderung menyelesaikan operasi penjumlahan pecahan seperti halnya menyelesaikan operasi penjumlahan pada bilangan bulat.

Kesalahan Konsep

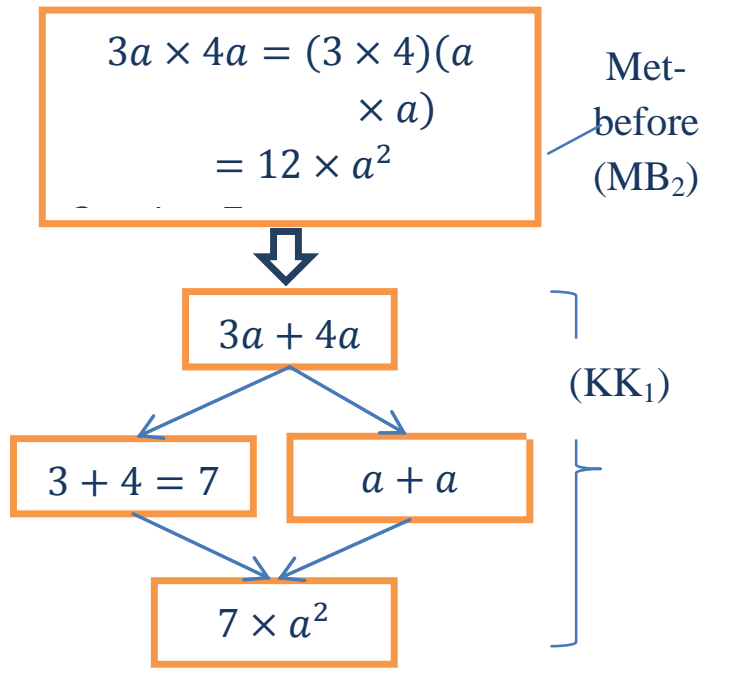

Gambar di samping menunjukkan adanya kesalahan konsep penjumlahan suku-suku aljabar sejenis dengan koefisien variabel tidak sama dengan 1 . Hal tersebut disebabkan oleh pengaitan siswa pada met- before nya tentang perkalian suku-suku aljabar sejenis dan operasi penjumlahan bilangan asli dengan penjumlahan suku-suku aljabar sejenis.

Gambar di samping menunjukkan adanya kesalahan konsep penjumlahan suku-suku aljabar sejenis dengan koefisien variable sama dengan 1. Hal tersebut disebabkan oleh pengaitan siswa pada met- before nya tentang perkalian suku-suku aljabar sejenis dengan penjumlahan suku-suku aljabar sejenis. 


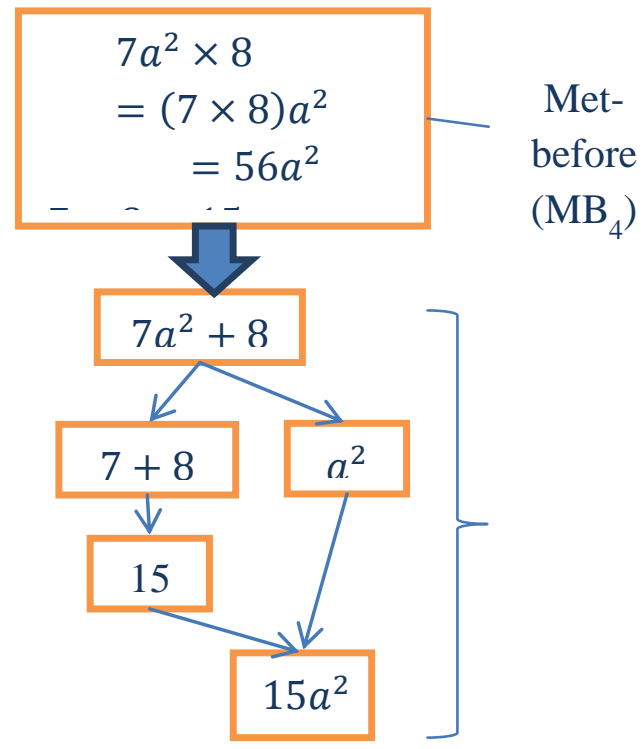

Gambar di samping menunjukkan adanya kesalahan konsep penjumlahan suku-suku aljabar yang tidak sejenis. Hal tersebut disebabkan oleh pengaitan siswa pada metbeforenya tentang perkalian suku-suku aljabar yang tidak sejenis dan operasi penjumlahan bilangan bulat dengan penjumlahan suku-suku aljabar yang tidak sejenis

b. Hasil analisis kesalahan subjek S dikaitkan dengan met-beforenya

Struktur Berpikir Subjek S

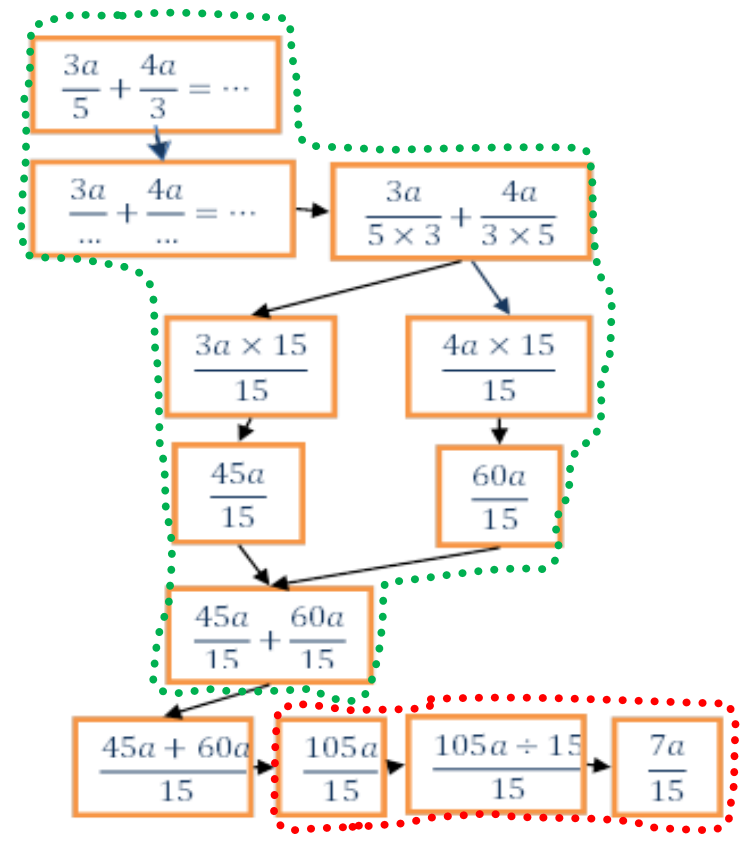

Struktur Masalah

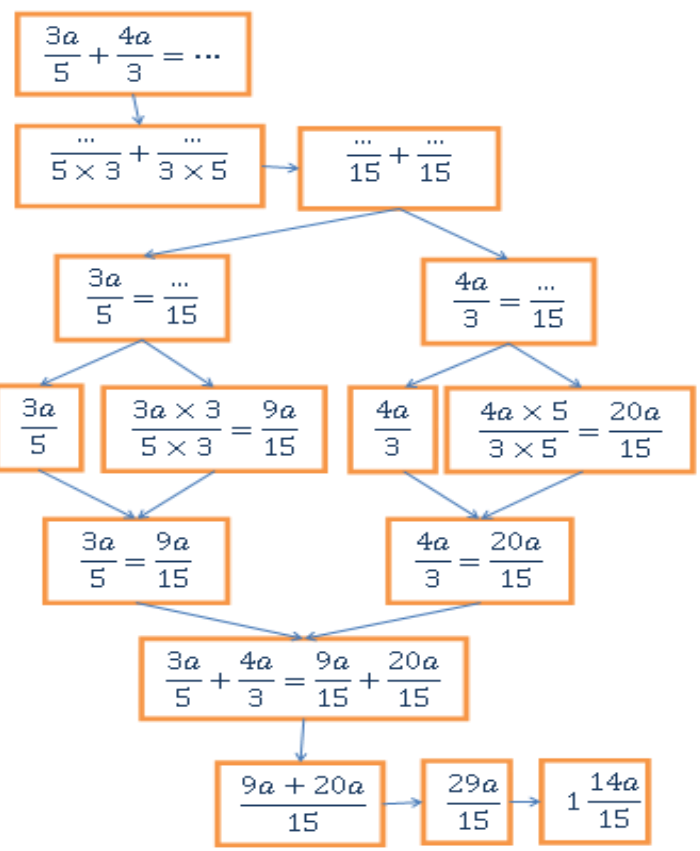

Keterangan:

" $=$ kesalahan prosedural (KP)

..... = kesalahan konsep pecahan senilai $(\mathrm{KK})$

Berdasarkan hasil wawancara dan hasil tes tertulis, ditemukan bahwa subjek $\mathrm{S}$ telah memahami soal dengan baik. Hal tersebut ditunjukkan dari struktur berpikir $\mathrm{S}$ yang mencoba untuk menyelesaikan operasi penjumlahan bentuk aljabar meskipun konsep yang digunakan masih ada yang salah, dan prosedur penyelesaian yang 
digunakan masih belum lengkap. Penggunaan konsep yang masih salah dan prosedur penyelesaian yang belum lengkap ditunjukkan oleh ketidaksesuaian antara stuktur berpikir subjek $\mathrm{S}$ dengan struktur masalah. Berikut adalah paparan penyebab ketidaksesuian antara struktur berpikir S dengan struktur masalah.

Kesalahan Prosedural

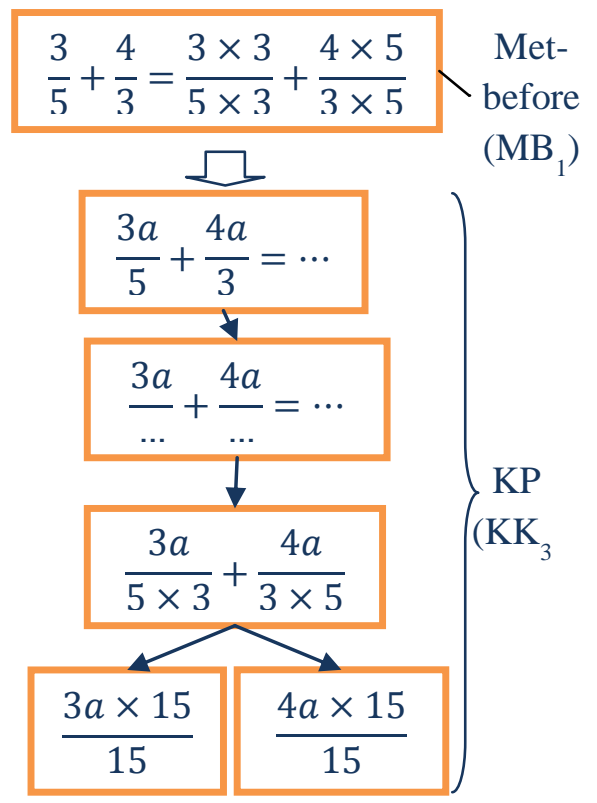

Gambar di samping menunjukkan bahwa met-before siswa terkait prosedur penyelesaian penjumlahan pecahan mengacaukan prosedur penyelesaian siswa pada penjumlahan pecahan bentuk aljabar. Hal tersebut terjadi karena siswa melakukan kesalahan dalam mengingat prosedur penyelesaian penjumlajan pecahan. Kesalahan tersebut disebabkan siswa hanya menghafal prosedur tanpa memahami konsep yang terkait dengan permasalahan, seperti konsep pecahan senilai. Kuramgnya pemahaman siswa pada konsep pecahan senilai mengakibatkan siswa melakukan kesalahan ketika mengkonversi masing-masing pecahan ke dalam bentuk pecahan senama dan senilai.

Kesalahan Konsep

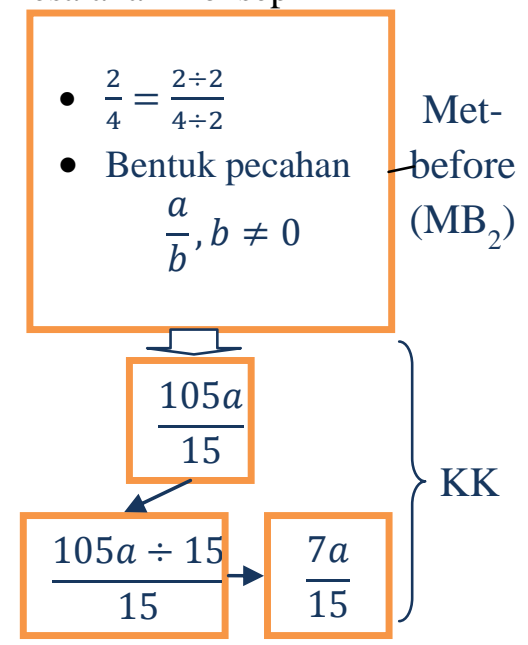

Gambar di samping menunjukkan bahwa met-before siswa terkait konsep menyederhanakan pecahan dan bentuk pecahan mengacaukan pemikiran siswa ketika dihadapkan pada penyederhanaan pecahan bentuk aljabar. Hal tersebut terjadi karena siswa tidak paham konsep pecahan senilai sehingga walaupun siswa mampu menemukan FPB dari pembilang dan penyebut, juga mampu untuk mengoperasikan pembagian antara pembilang dengan FPB, tetap saja siswa tidak menemukan jawaban yang benar. 
c. Hasil analisis kesalahan subjek T dikaitkan dengan met-beforenya

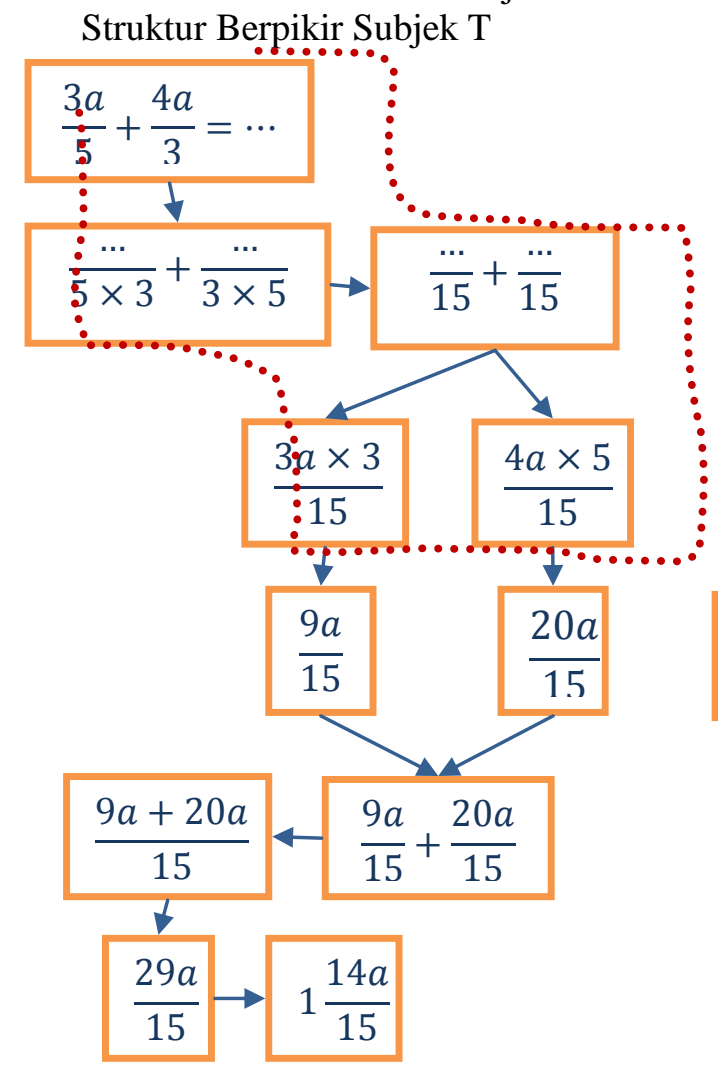
Struktur Masalah

Keterangan:

$$
\frac{3 a}{5}+\frac{4 a}{3}=\cdots
$$

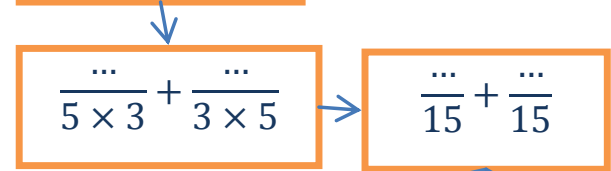

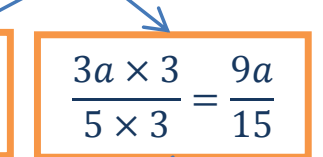

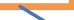

\author{
(1)
}




\section{KESIMPULAN}

Berdasarkan paparan data di atas dan hasil wawancara peniliti dengan siswa dan guru dari subjek dalam penelitian ini, maka peneliti menyimpulkan bahwa:

1. Siswa dalam mengkonstruksi konsep penjumlahan pecahan bentuk aljabar masih melakukan kesalahan matematika. Kesalahan tersebut dipengaruhi oleh metbefore siswa.

2. Subjek berkemampuan rendah belum memiliki skema yang sesuai dengan struktur masalah terkait penjumlahan pecahan bentuk aljabar. Hal ini terjadi karena siswa masih melakukan kesalahan prosedural dan konseptual dalam mengkonstruksi konsep tersebut. Kesalahan terjadi karena pemikiran siswa dikacaukan oleh met-beforenya terkait operasi penjumlahan suku-suku aljabar, operasi penjumlahan bilangan bulat, dan perkalian suku-suku aljabar. Selain itu, kesalahan tersebut juga disebabkan oleh pengetahuan terkait met-before siswa yang belum lengkap dan tidak ada yang terkait dengan penyelesaian operasi penjumlahan pecahan bentuk aljabar. Akibatnya, meskipun pengetahuan terkait met-before siswa dalam memecahkan masalah ada yang pemahamannya benar, tetap saja pemikiran siswa masih kacau dalam mengkonstruksi konsep penjumlahan pecahan bentuk aljabar.

3. Subjek berkemampuan sedang sudah memiliki skema yang sesuai dengan struktur masalah terkait penjumlahan pecahan bentuk aljabar, namun belum lengkap. Hal ini terjadi karena siswa masih melakukan kesalahan prosedural dan konseptual dalam mengkonstruksi konsep tersebut. Siswa melakukan kesalahan prosedural karena dikacaukan oleh met-beforenya terkait prosedur penyelesaian operasi penjumlahan pecahan dan pemahaman konsep pecahan senilai yang masih kurang. Siswa melakukan kesalahan konseptual dalam menyederhanakan pecahan karena dikacaukan oleh met-beforenya terkait konsep pecahan senilai dan bentuk pecahan. Kekacauan pemikiran siswa dalam mengkonstruksi konsep penjumlahan pecahan bentuk aljabar terjadi karena met-before yang dikaitkan siswa untuk menyelesaikan operasi penjumlahan pecahan bentuk aljabar belum cukup, dan pemahaman terhadap pengetahuan yang terkait dengan met-before siswa tersebut masih ada yang salah.

4. Subjek berkemampuan tinggi sudah memiliki skema yang sesuai dengan struktur masalah terkait penjumlahan pecahan bentuk aljabar, tetapi belum lengkap. Hal ini terjadi karena meskipun met-before yang dimiliki siswa terkait pemecahan masalah tersebut sudah lengkap, dan pemahaman terhadap pengetahuan yang terkait dengan met-before siswa juga sudah benar, tetapi siswa belum bisa mengaitkan met-beforenya terkait konsep pecahan senilai dalam mengkonversi pecahan bentuk aljabar ke dalam bentuk pecahan aljabar yang senama dan senilai. Padahal sebenarnya siswa sudah memahami konsep pecahan senilai dengan baik.

\section{DAFTAR PUSTAKA}

Barrera, dkk. 2004. Cognitive Abilities And Errors Of Students In Secondary School In Algebraic Language Processes. Proceedings of the twenty-sixth annual meeting of the North American Chapter of the International Group for the Psychology of Mathematics Education. Volume 1. 
Dhlamini. 2014. Grade 9 Learners' Errors And Misconceptions In Addition Of Fractions. Mediterranean Journal of Social Sciences. Vol 5, No. 8, ISSN 2039-2117 (online) ISSN 2039-9340 (print). Publishing: MCSER

Elbrink. 2007. Analyzing and Addressing Common Mathematical Errors in Secondary Education. B.S. Undergraduate Mathematics Exchange, Vol. 5, No. 1.

Ganesan \& Dindyal. 2014. An Investigation of Students' Errors in Logarithms. Proceedings of the 37th annual conference of the Mathematics Education Research Group of Australasia. pp. 231-238. Sydney: MERGA.

Godden, dkk. 2013. An Analysis Of Errors And Misconceptions In The 2010 Grade 12 Mathematics Examination: A Focus On Quadratic Equations And Inequalities. Proceedings of the 19th Annual Congress of the Association for Mathematics Education of South Africa. Vol. 1. (pp. 70 - 79). Cape Town: AMESA.

Huang \& Cheng. 2010. Analyzing Errors Made by Eighth-Grade Students in Solving Geometrical Problems in China. The Mathematics Educator. Vol. 12, No.2, 63-80.

Idris \& Narayanan. 2011. Error Patterns in Addition and Subtraction of Fractions among Form Two Students. Journal of Mathematics Education. Vol. 4, No. 2, pp. 35-54.

Kiat. 2005. Analysis of Students' Difficulties in Solving Integration Problems. The Mathematics Educator. Vol. 9, No.1, 39-59.

Maat, dkk. 2010. Analysis of Students' Error in Learning of Quadratic Equations. International Education Studies. Vol. 3, No. 3.

Riccomini 2005. Identification And Remediation Of Systematic Error Patterns In Subtraction. Summer. Volume 28.

Seng. 2010. An Error Analysis Of Form 2 (Grade 7) Students In Simplifying Algebraic Expressions: Descrictive Study. Electronic journal of research in educational psycologhy, 8(1), 139-162, ISSN: 1696-2095.

Tall, D. O. 2002. Continuities and Discontinuities in Long-Term Learning Schemas (reflecting on how relational understanding may be instrumental in creating learning problems). In David Tall \& Michael Thomas (eds), Intelligence, Learning and Understanding in Mathematics - A Tribute to Richard Skemp, 151-177. Flaxton, Australia: Post Pressed.

Tall, D. O. 2004. Thinking Through Three Worlds of Mathematics. Proceedings of the 28th Conference of the International Group for the Psychology of Mathematics Education. Bergen, Norway, 4, 281-288.

Yusof \& Malone. 2002. Mathematical Errors in Fractions: A Case of Bruneian Primary 5 Pupils. University of Technology

White. 2010. Numeracy, Literacy and Newman's Error Analysis. Journal of Science and Mathematics Education in Southeast Asia. Vol. 33, No. 2, 129 - 148. 